Research paper

\title{
Estimates of repeatability and correlations of hemoparasites infection levels for cattle reared in endemic areas for Rhipicephalus microplus
}

\author{
Rodrigo Giglioti ${ }^{\mathrm{a}, *}$, Henrique Nunes de Oliveira ${ }^{\mathrm{a}}$, Talita Barban Bilhassi ${ }^{\mathrm{a}}$, Amanda Izeli Portilho ${ }^{\mathrm{b}}$, \\ Cintia Hiromi Okino ${ }^{\mathrm{b}}$, Cintia Righetti Marcondes ${ }^{\mathrm{b}}$, Marcia Cristina de Sena Oliveira ${ }^{\mathrm{b}}$

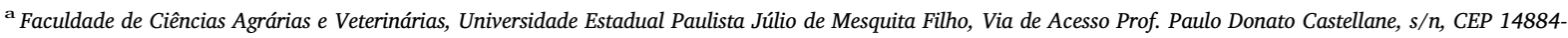 \\ 900, Jaboticabal, São Paulo, Brazil

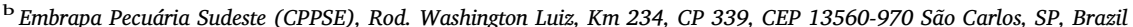

\section{A R T I C L E I N F O}

\section{Keywords:}

Tick fever

qPCR

Repeatability

Association

Cattle

\begin{abstract}
A B S T R A C T
Rhipicephalus microplus is a vector of cattle tick fever, a disease caused by the protozoans Babesia bovisand $B$. bigemina, and also anaplasmosis, produced by the Rickettsiales Anaplasma marginale. These tick-borne pathogens cause considerable losses to Brazilian livestock breeders and represent an obstacle to the expanded use of taurine breeds due to their higher sensitivity to ticks and hemoparasites compared to zebu breeds. Differences in the susceptibility to hemoparasites were also verified within breeds, suggesting that may be possible to select a most resistant phenotype. Therefore, repeatability of $R$. microplus counts and copy number of hemoparasites DNA were estimated, along with correlations between themselves, aiming to verify if those measures can be used as parameters to classify animals according to their parasite resistance degrees. Forty-two Canchim females kept on pastures naturally infested by ticks were evaluated for the level of infestation by $R$. microplus and infection by $B$. bovis, B. bigemina, and A. marginale. Twenty-four evaluations were performed once a month, for adult female ticks counts and blood samplings. The experimental period was divided into four phases, according to the animals age range: Phase 1: 8 to 13 months (collections 1 to 6); phase 2: 14 to 19 months (collections 7 to 12 ); phase 3: 20 to 25 months (collections 13 to 18), and phase 4: 26 to 31 months (collections 19 to 24). Blood samples were submitted to absolute quantification of hemoparasites DNA sequences using qPCR. The hemoparasite and tick counts data were transformed for normalization and were analyzed using mixed models. Among three species of hemoparasites studied, A. marginale presented the highest level of infection. During phase $3, B$. bigemina presented higher infection levels $(p<0.05)$ compared to $B$. bovis, whereas no differences were observed in other phases. Estimated repeatabilities for parasite infection levels varied from low to moderate during our experiment. There were low correlations between tick counts and parasite infection levels, and between parasite infection levels from different species by themselves. Based on these results, under conditions of the present study, we suggest that it is possible to identify animals presenting a most resistant phenotype against infection by both hemoparasites and ticks. Moreover, the animal age may be an important factor related to resistance against these pathogens. The data obtained shed more light on the resistance to hemoparasites studied.
\end{abstract}

\section{Introduction}

The protozoans Babesia bovis and B. bigemina and Rickettsiales Anaplasma marginale are hemoparasites of cattle transmitted by the tick Rhipicephalus microplus. These hemoparasites cause significant losses to the livestock industry in tropical and subtropical regions of the world (Jongejan and Uilenberg, 1994; Bock et al., 2004). The economic impacts generated by babesiosis and bovine anaplasmosis are not restricted to mortality, but also to morbidity, miscarriages, lower meat and milk production, spending on veterinary services, and restrictions on international trade in cattle products (Kocan et al., 2003; Bock et al., 2004). The most significant damage caused by bovine babesiosis is attributed to $B$. bovis, due to its increased pathogenicity. Primary infections in susceptible cattle lead to cerebral, renal and or pulmonary dysfunctions or failures and are often fatal (Wright and Goodger, 1988; Clark and Jacobsen, 1998; Schetters and Eling, 1999; Brown et al., 2006).

The occurrence of these hemoparasites in bovines is first dependent

\footnotetext{
* Corresponding author at: Embrapa Pecuária Sudeste, Rodovia Washington Luiz, Km 234, CP 339, 13560-970, São Carlos, São Paulo, Brazil.

E-mail address: gigliotirodrigo@gmail.com (R. Giglioti).
} 
on the population dynamics of the tick, which needs favorable climatic conditions for its development (Mahoney and Ross, 1972). The regions where tick occurrence is constant are classified as areas of endemic stability (Mahoney, 1962; Mahoney and Ross, 1972). In this condition, cattle are constantly infected by these agents, developing stronger immunity and becoming healthy carriers (Bock et al., 2004).

The diagnosis of these diseases in clinically affected animals is usually made through of microscopic examination of peripheral blood smears (Bock et al., 2004; Calder et al., 1996; Sahinduran, 2012). The detection of carrier animals requires the use of more sensitive techniques as PCR and qPCR (Oliveira et al., 2005; Oliveira-Sequeira et al., 2005; Buling et al., 2007; Ramos et al., 2011; Bilhassi et al., 2014; Giglioti et al., 2016; Giglioti et al., 2017).

Zebu breeds are most commonly used in tropical regions of the world due to their enhanced resistance to ticks and tick-borne diseases. The use of crosses between taurine and zebu breeds is a strategy that aims to improve productivity and is attracting the interest of Brazilian producers who want to increase the efficiency of their herds (Ibelli et al., 2012). However, losses caused by hemoparasite infections and tick infestations limit the increase in productivity through the introduction of taurine breeds and their crosses in beef cattle breeding systems (Oliveira et al., 2014). Despite, studies have already evaluated the possibility of performing phenotypic selection (Fraga et al., 2003), and more recently of genome selection for tick resistance (Cardoso et al., 2015), few studies have evaluated the resistance to hemoparasites by quantitative methods. The survey by Giglioti et al. (2016) was the first to estimate repeatability and correlations between $B$. bovis and $B$. bigemina infection levels in beef cattle. The authors evaluated naturally tick infested Angus bulls and found low values for repeatability for $B$. bovis infection in two subsequent measurements and poor correlation between the $R$. microplus infestations and the level of B. bovis infection. The genetic improvement by selection for resistance to hemoparasites in taurines or breeds originated from their crosses, if possible, would be an alternative to facilitate the control of this disease, and consequently, would encourage breeders to use more productive animals.

In this experiment, we evaluated the Canchim breed $(5 / 8$ Charolais $+3 / 8 \mathrm{Zebu}$ ) characterized by its high resistance to the tropical conditions, which is a predominant climate of the Brazilian territory, though according to some authors (Oliveira and Alencar, 1987; Oliveira et al., 1989), this breed presents only medium resistance to ticks. Scarce information is available regarding the susceptibility of this breed to babesiosis. We evaluated the levels of $R$. microplus infestation and $A$. marginale, B. bovis and B. bigemina infection in 42 Canchim females, reared in an area previously identified as endemic for babesiosis (Oliveira et al., 2008). The coefficients of repeatability of $R$. microplus counts and the DNA copy number $(\mathrm{CN})$ of the hemoparasites were estimated, along with the correlations between themselves, to verify if those measures can be used as parameters to classify animals according to their parasite resistance degrees and if the parasitemia for one hemoparasite can influence another.

\section{Materials and methods}

\subsection{Animals and sample collection}

The study was performed at the experimental farm of Embrapa, São Carlos, São Paulo state, Brazil (21 $57^{\circ} 42^{\prime \prime} \mathrm{S}, 47^{\circ} 50^{\prime} 28^{\prime \prime} \mathrm{W}$ and $860 \mathrm{~m}$ altitude). The local climate is considered to be tropical altitude, CWA on the Köppen scale, characterized by relatively cold and dry winters and hot and humid summers. This region is deemed to be endemic for the occurrence of $R$. microplus and the hemoparasites transmitted by these vectors (Oliveira et al., 2008; Bilhassi et al., 2014; Giglioti et al., 2017). Currently, there are three lineages of Canchim breed (5/8 Charolais $+3 / 8 \mathrm{Zebu}$ ): the first formed of crosses that started in 1940 and have been kept as a closed herd since 1953; a new lineage formed in 1986 by crossing Canchim x Nelore crossbred females with Charolais bulls, and another cross lineage formed between animals of these two strains. In this study, only animals from the old (OL) and new (NL) lineages were used. We used 42 Canchim females, which entered the experiment after weaning with ages ranging between eight and ten months. The animals were maintained in Tanzania grass paddocks (Panicum maximum). Data were collected for 24 months (August 2013 to July 2015) at intervals of 28-30 days, for a total of 1,008 observations for each characteristic evaluated. All collections were carried out in the morning, until 9:00 am, avoiding rainy days. From each animal, all adult female ticks larger than $4 \mathrm{~mm}$ in diameter were counted on the left side of the body, and the values of each count were multiplied by two to determine the total number of ticks on each host, according to Wharton and Utech (1970). Simultaneously, blood samples were taken from the jugular vein using a vacuum system (Vacutainer ${ }^{\circledR}$, Becton Dickinson) containing EDTA anticoagulant. The samples were properly identified, packed in ice and taken to the laboratory. During the experimental period, the monthly average of air temperature ranged from $17.7^{\circ} \mathrm{C}$ to $24.7{ }^{\circ} \mathrm{C}$, and total precipitation ranged from $4.4 \mathrm{~mm}$ to 495 $\mathrm{mm}$. On five occasions (February, July and October 2014, April and May 2015), when the tick count reached an average of 50 or more ticks per animal, the herd was treated with commercial acaricide based on pyrethroids and organophosphates (Colosso ${ }^{\circledR}$, Ourofino Saúde Animal). This acaricide has a withholding period of ten days, which allowed new infestations by ticks for subsequent counts. The experimental period was divided into four phases, with six collections per phase according to the age range of the animals: Phase 1: 8 to 13 months (collections 1 to 6 - August 2013 to January 2014); phase 2: 14 to 19 months (collections 7 to 12 - Febuary to July 2014); phase 3: 20 to 25 months (collections 13 to 18 - August 2014 to January 2015), and phase 4: 26 to 31 months (collections 19 to 24 - Febuary to July 2015). Each phase was individually analyzed for statistical analysis. This experiment was in agreement with ethical principles of animal experimentation of the Embrapa Southeast Livestock ethics committee for animal experiments (CEUA-Embrapa, PRT no. 03/2014).

\subsection{DNA extraction}

The genomic DNA was extracted from $300 \mathrm{~mL}$ of each blood sample, using the Easy-DNA ${ }^{\mathrm{TM}}$ kit (Invitrogen USA, catalog number: K180001) according to the manufacturer's protocol (Protocol \#2-30 Minute DNA Extraction from Blood Samples) and eluted in $200 \mathrm{~mL}$ of TE buffer. All samples were identified and stored at $-80^{\circ} \mathrm{C}$ until further analysis.

\section{3. qPCR tests}

All qPCR tests were performed using CFX $^{\mathrm{TM}}$ Real-Time PCR Detection System (BioRad) and SsoFast ${ }^{\mathrm{TM}}$ EvaGreen $^{\circledast}$ Supermix (BioRad) reagents. Absolute quantification for B. bovis and B. bigemina DNA copies were carried according previously published (Buling et al., 2007), using optimized protocols and standard curves described by Giglioti et al. (2016, 2017), while for A. marginale, a qPCR method was adapted based on a previous study (Carelli et al., 2007) using primers flanking a fragment of 95 nucleotides located in the gene encoding the major surface protein $1 \mathrm{~b}$ (msp1b).

Briefly, qPCR was conducted in a final volume of $12 \mu \mathrm{L}$, using $6 \mu \mathrm{L}$ of Supermix Reagent (BioRad), $0.3 \mu \mathrm{L}$ of each primer $(10 \mu \mathrm{M})$, and $2.0 \mu \mathrm{L}$ of DNA sample. The thermal profile was one step of $2 \mathrm{~min}$ at $98^{\circ} \mathrm{C}$, followed by 45 cycles (except for A. marginale, which were 40 cycles) at $98^{\circ} \mathrm{C}$ for $10 \mathrm{~s}$ and $60^{\circ} \mathrm{C}$ (annealing/extension/reading) for $30 \mathrm{~s}$. After amplification, a melting analysis was generated by raising the incubation temperature from $65^{\circ} \mathrm{C}$ to $95^{\circ} \mathrm{C}$ in $0.5^{\circ} \mathrm{C}$ increments with a hold step of $1 \mathrm{sec}$ at each increment. All reactions were run in duplicate.

The calibration curve for A. marginale was constructed using synthetic DNA, gBlocks ${ }^{\circledast}$ Gene Fragments (IDT, Coralville, IA, USA). The gBlocks $^{\circledast}$ fragment containing the target sequence of $A$. marginale msp $1 b$ 
(Carelli et al., 2007), was firstly diluted following the manufacturer's recommendations, obtaining a final concentration of $5 \mathrm{ng} / \mu \mathrm{L}$, and then submitted to 10 -fold serial dilutions $\left(10^{-1}\right.$ to $\left.10^{-10}\right)$ and qPCR. The CN of molecules from the target DNA at each dilution was calculated by the formula described by Ke et al. (2006). The reaction efficiency (E) (Pfaffl, 2001; Vandesompele et al., 2002), expressed as a percentage, was determined by the following formula: $\% \mathrm{E}=\left(10^{(-1 / \text { Slope })}\right.$ $-1 \times 100$ ), where Slope $=$ slope of the derivative (tangent line) of the calibration curve. All samples presenting a standard deviation greater than 0.5 of the cycle quantification $(\mathrm{Cq})$ regarding the duplicate were re-analyzed.

To assess the specificity of qPCR for DNA quantification of $B$. bovis, $B$. bigemina and A. marginale, DNA extracted from hemoparasites previously isolated from the microbial collection at Embrapa Southeast Livestock, São Carlos, SP, were also tested. The reactions were carried out in triplicate. The specificity was determined based on the results of the amplification and the melting curve values. The analytical sensitivities for B. bigemina, B. bovis, and A. marginale detection and quantification were estimated from the DNA samples from isolates of each species diluted to a final concentration of $1 \mathrm{ng} / \mu \mathrm{L}$. Then, the samples were submitted to serial 10 -fold dilutions $\left(10^{-1}\right.$ to $\left.10^{-10}\right)$, using five replicates and were submitted to qPCR runs for each species. The cutoff point for each species was determined as the last dilution (least concentrated sample) that amplified more than $50 \%$ of the samples (Caraguel et al., 2011). For each sensitivity test, a calibration curve was plotted with diluted samples to verify the reproducibility and the reaction efficiencies (E).

\subsection{Statistical analysis}

The data from tick counts and $\mathrm{CN}$ were transformed into $\log 10$ $(n+1)$ to approximate the normal distribution, and the analyses were conducted separately for each age phase using the mixed model method. Two different models were used: (i) to estimate the repeatability, and (ii) to estimate associations between species and comparison of means. The model ( $i$ ) was applied to each species of parasite separately and included repeated measurements of the same animal, and the fixed effects of collection, lineage and their interactions. A compound symmetry (CS) was assumed as the structure for the (co) variance matrix. The model (ii) was multivariate with repeated measurements in the same animal, including the fixed effects of the collection, species (three hemoparasites and tick) lineage and their interactions. In this model, we used a structure of the (co)variance matrix of direct product structures (UN@CS) designed for multivariate repeated measures. This structure is constructed by taking the Kronecker product of an unstructured matrix - UN (modeling covariance between species) with an additional covariance matrix of compound symmetry (CS) (modeling covariance across time). The MIXED procedure of the SAS ${ }^{\circledR}$ statistical package was used for the analyses.

\section{Results}

3.1. Specificity and analytical sensitivity for detection of B. bigemina, $B$. bovis and $A$. marginale by $q P C R$

The specificity of qPCR assays were confirmed, as different melting peak temperatures were obtained: $77.5^{\circ} \mathrm{C}, 76.0^{\circ} \mathrm{C}$ and $83^{\circ} \mathrm{C}$ for $B$. bovis, $B$. bigemina and A. marginale, respectively (Fig. 1). Limit of detection for B. bovisand B. bigemina qPCRs, was determinedat up to 12 copies of target DNA in blood samples, while mean cutoff point corresponded to Cq 39 (concentration: $1 \mathrm{ng} / \mu \mathrm{L} \times 10^{-5}$ ). For $A$. marginale, the qPCR was able to detect up to 30 DNA copies, and the cutoff point was Cq 36 (concentration: $1 \mathrm{ng} / \mu \mathrm{L} \times 10^{-4}$ ). All samples presenting $\mathrm{Cq}$ values above these defined cutoff points were classified as negative. Efficiency (E) values were estimated at $97.5 \%, 90.1 \%$, and $95.6 \%$, for $B$. bovis, $B$. bigemina, and $A$. marginale qPCRs, respectively during this sensitivity

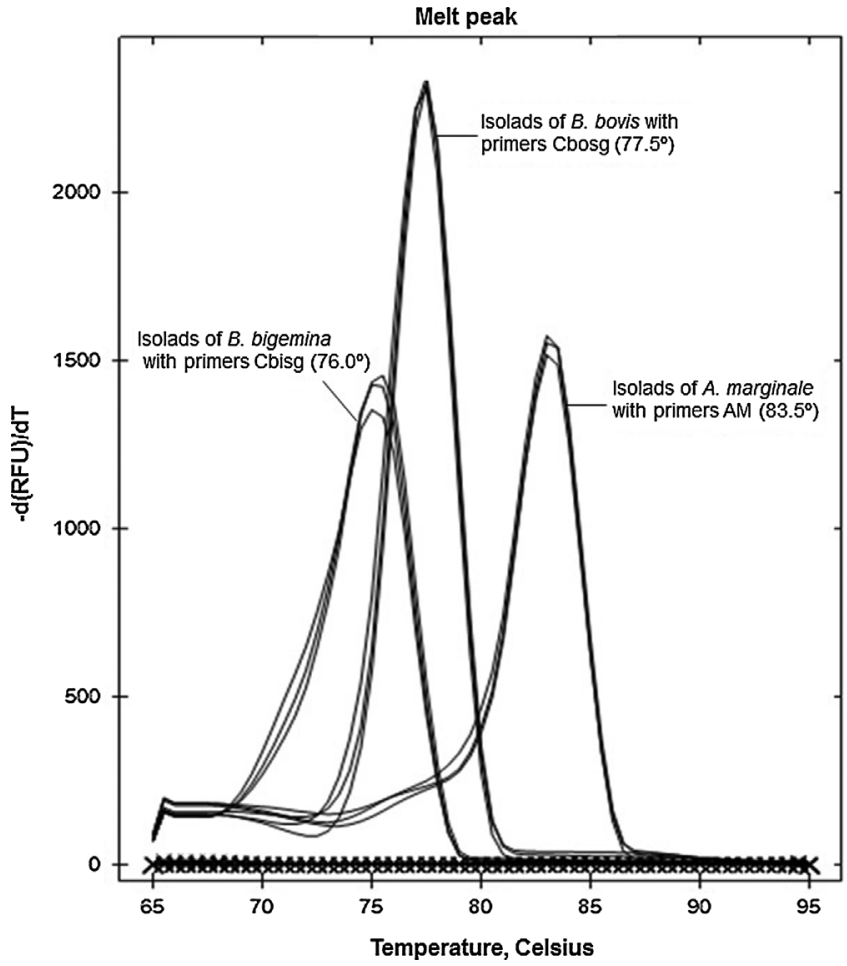

Fig. 1. Specificity of the $m t-c y B$ primers of B. bovis (Cbosg 1 and 2), B. bigemina (Cbisg 1 and 2) and the $m s p 1 b$ primers of $A$. marginale (AM 1 and 2). The amplification of each primer pair was specific. The temperature values of the peak curve for B. bovis, B. bigemina, and A. marginale were $77.5^{\circ} \mathrm{C}, 76.0^{\circ} \mathrm{C}$, and $83.0^{\circ} \mathrm{C}$, respectively. $\mathrm{RFU}=$ Relative fluorescence unit.

analytical test (Fig. 2, A1, A2, and A3). Fig. 2 (B1 to B3 and C1 to C3) shows three representative assays, each containing a calibration curve and indicating the DNA samples amplified along with the positive and negative controls for DNA quantification of B.bovis, B. bigemina, and $A$. marginale DNA, respectively. It is possible to note in Fig. 2 (B1, B2, and B3) that in all three assays, all DNA samples were positive and quantified because they were within the quantification range of the calibration curve. Furthermore, in each of the three tests, the cutoff point appeared close to the lowest concentration of the calibration curve in the case of $B$. bovis and B. bigemina, or together in the case of $A$. marginale.

\subsection{Tick counts and copy numbers}

In each of the analyzed phases, the effect of the collection on the tick count was significant $(p<0.01)$. Only for phase two was found a significant difference $(p<0.01)$ between OL and NL lineages, with averages and standard errors $0.53 \pm 0.06$ and $0.81 \pm 0.06$, respectively. However, the interaction of lineage with the collection was not evidenced. The distribution of tick counts for the four phases, covering the 24 collections is shown in Fig. 3.

Regarding the mean infection rates considering all collections, $95.6 \%, 91.0 \%$ and $98.3 \%$ of cattle DNA samples were positive and quantified for B. bovis, B. bigemina, and A. marginale, respectively. Most of the animals were positive for hemoparasites until the collection of April 2015, when they were approximately 28 to 30 months old (Table 1). For $A$. marginale, the positive frequencies remained high during the whole experimental period, while for $B$. bovis and B. bigemina there was a sharp decline of positive animals from May 2015, when they were between 29 and 31months old. It is important to note that for $B$. bovisall animals were positive up to the tenth collection (July 2014). Regarding A. marginale, the month with the lowest positive frequency was December 2014 (88.1\%), but in most collections, the positive 

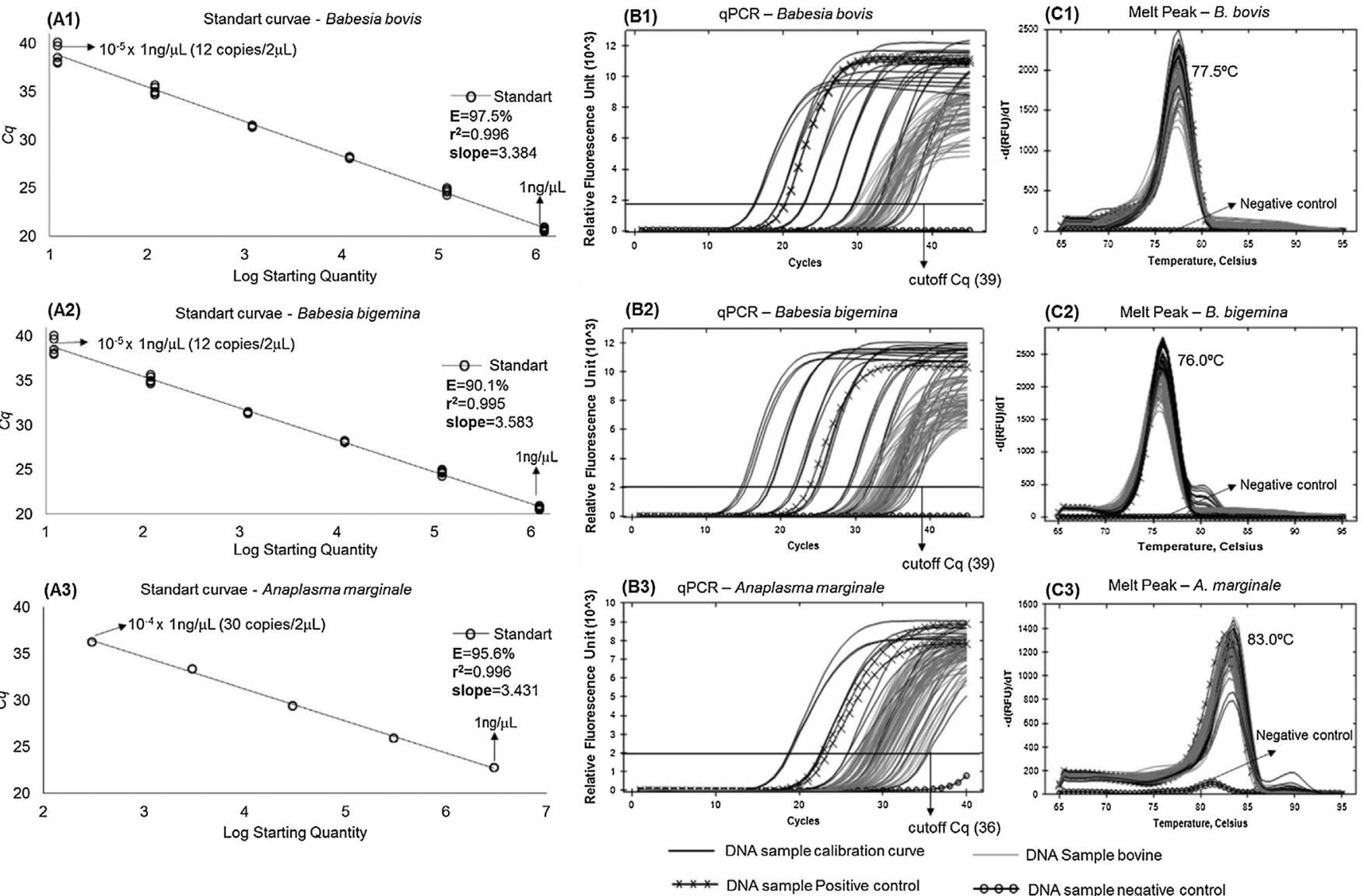

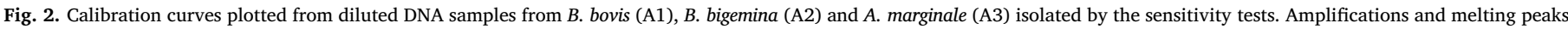

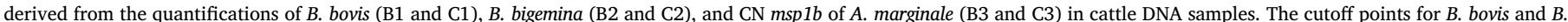

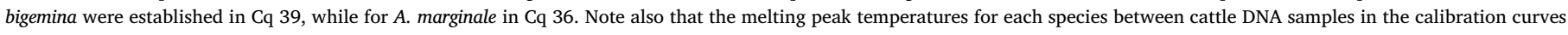
and positive controls were the same.

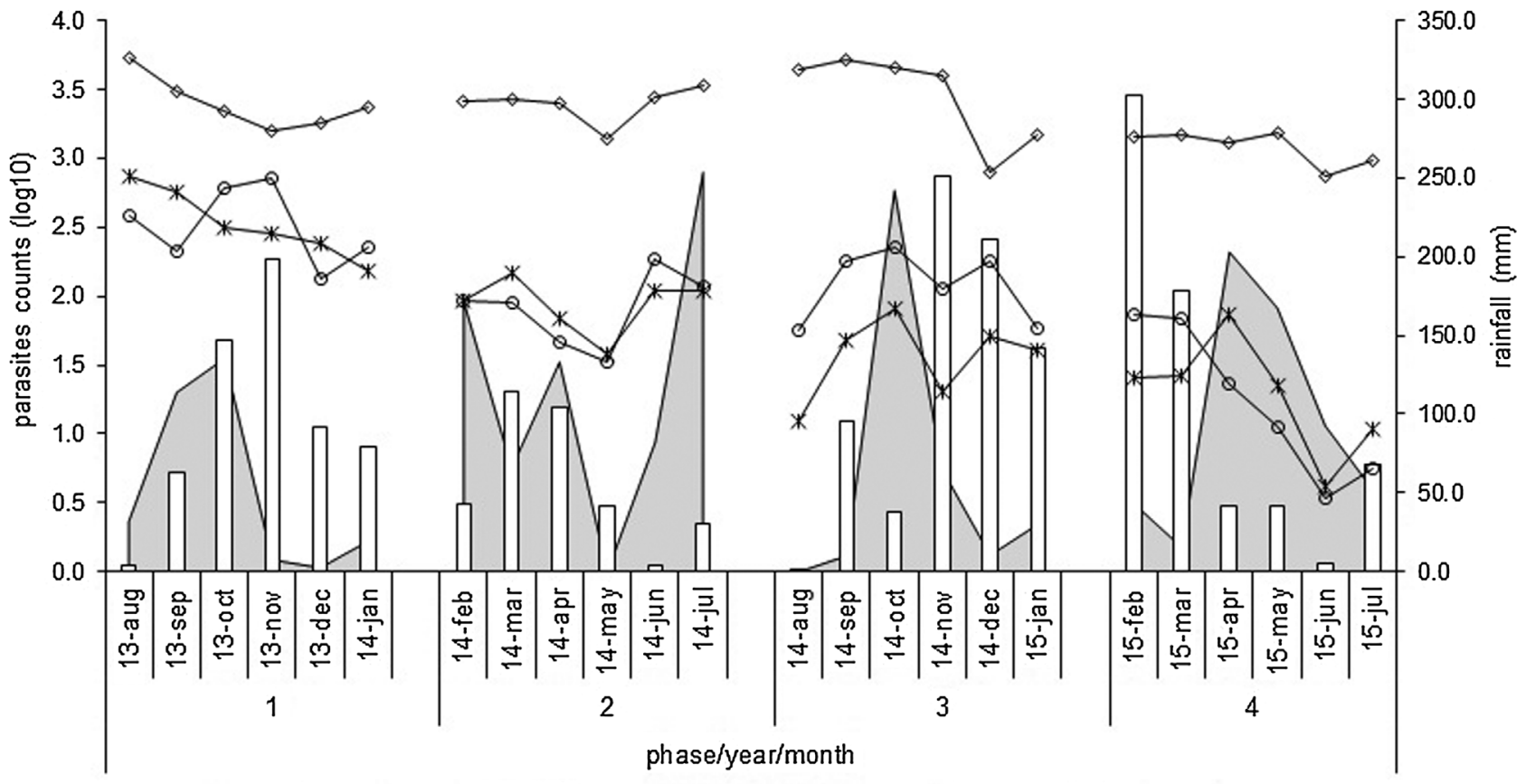

$\square R$ microplus $\square$ rain (mm) ๑NC-A. marginale -NC-B. bigemina $\rightarrow-N C-B$. bovis

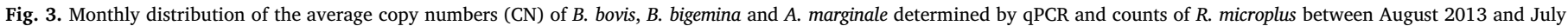
2015, separated by phase. 
Table 1

Positive frequency of animals detected by qPCR assays (based on the cutoff point of each hemoparasite species) for B. bovis, B. bigemina and A. marginale between August 2013 and July 2015.

\begin{tabular}{|c|c|c|c|c|}
\hline \multirow[b]{2}{*}{ Year } & \multirow[b]{2}{*}{ Month } & \multicolumn{3}{|c|}{ Positive frequency (\%) } \\
\hline & & A. marginale & B. bovis & B. bigemina \\
\hline \multirow[t]{5}{*}{2013} & Aug & 97.6 & 100.0 & 100.0 \\
\hline & Sep & 97.5 & 100.0 & 92.5 \\
\hline & Oct & 94.9 & 100.0 & 100.0 \\
\hline & Nov & 100.0 & 100.0 & 100.0 \\
\hline & Dec & 95.0 & 100.0 & 97.5 \\
\hline \multirow[t]{12}{*}{2014} & Jan & 100.0 & 100.0 & 100.0 \\
\hline & Feb & 100.0 & 100.0 & 97.6 \\
\hline & Mar & 100.0 & 100.0 & 92.9 \\
\hline & Apr & 100.0 & 100.0 & 95.2 \\
\hline & May & 100.0 & 100.0 & 85.7 \\
\hline & Jun & 100.0 & 100.0 & 100.0 \\
\hline & Jul & 100.0 & 100.0 & 97.6 \\
\hline & Aug & 100.0 & 90.5 & 88.1 \\
\hline & Sep & 100.0 & 97.6 & 97.6 \\
\hline & Oct & 100.0 & 100.0 & 100.0 \\
\hline & Nov & 97.6 & 95.2 & 100.0 \\
\hline & Dec & 88.1 & 97.6 & 97.6 \\
\hline \multirow[t]{8}{*}{2015} & Jan & 97.6 & 95.2 & 95.2 \\
\hline & Feb & 95.1 & 87.8 & 97.6 \\
\hline & Mar & 100.0 & 95.2 & 95.2 \\
\hline & Apr & 97.6 & 100.0 & 85.7 \\
\hline & May & 100.0 & 88.1 & 76.2 \\
\hline & Jun & 97.6 & 56.1 & 43.9 \\
\hline & Jul & 100.0 & 90.2 & 46.3 \\
\hline & Total & 98.3 & 95.6 & 91.0 \\
\hline
\end{tabular}

Table 2

Transformed means (log10) followed by standard errors of copy numbers of $B$. bovis, $B$. bigemina and A. marginale and R. microplus by phases.

\begin{tabular}{lllll}
\hline & \multicolumn{2}{l}{ Copy numbers $/ \mu \mathrm{L}$} & \multirow{2}{*}{ R. microplus counts } \\
\cline { 2 - 4 } Phase & A. marginale & B. bigemina & B. bovis & \\
\hline 1 & $3.40 \pm 0.05 \mathrm{a}$ & $2.51 \pm 0.05 \mathrm{~b}$ & $2.52 \pm 0.05 \mathrm{~b}$ & $0.29 \pm 0.05$ \\
2 & $3.41 \pm 0.05 \mathrm{a}$ & $1.92 \pm 0.05 \mathrm{~b}$ & $1.95 \pm 0.05 \mathrm{~b}$ & $0.68 \pm 0.05$ \\
3 & $3.45 \pm 0.05 \mathrm{a}$ & $2.08 \pm 0.05 \mathrm{~b}$ & $1.56 \pm 0.05 \mathrm{c}$ & $0.34 \pm 0.05$ \\
4 & $3.08 \pm 0.05 \mathrm{ab}$ & $1.23 \pm 0.05 \mathrm{~b}$ & $1.28 \pm 0.05 \mathrm{~b}$ & $0.55 \pm 0.05$ \\
\hline
\end{tabular}

*Means followed by the different letters on the same line differ significantly $(p<0.05)$.

frequencies were close to $100 \%$.

In the analyses of the quantifications of $\mathrm{CN}$ for the four age phases considered, significant effects of parasite species, collection, and species $\mathrm{x}$ collection interaction $(p<0.05)$ were observed. Significant differences $(p<0.05)$ of DNA CN of $B$. bovis were observed between two Canchim lineages, only in phase two, and averages followed by standard errors were $1.80 \pm 0.07$ and $2.07 \pm 0.05$, for OL and NL, respectively. The $\mathrm{CN}$ values calculated for $A$. marginale were significantly higher compared to $B$. bovisand $B$. bigemina, during the whole experimental period (Table 2). Only in phase three, the $\mathrm{CN}$ of $B$. bigemina differed significantly $(p<0.05)$ from $\mathrm{CN}$ of $B$. bovis (Table 2). Phase 4 showed the lowest infection level of all three hemoparasite species. Fig. 3 shows $\mathrm{CN}$ distribution of three hemoparasite species, tick counts, and total precipitation during the 24-month period (August 2013 to July 2015). For all three hemoparasites species, there was a decrease in the $\mathrm{CN}$ over time. This decline was more evident for babesias than for $A$. marginale. As shown in Table 1, the reduction of mean $C N$ values of $B$. bigemina and $B$. bovis may be due to the greater number of negative animals that occurred in the last three collections.

\subsection{Repeatabilities and correlations}

The repeatability estimates found for tick counts ranged from low to
Table 3

Estimated repeatabilities and correlations of the $\mathrm{CN}$ for $A$. marginale, B. bigemina, $B$. bovis and $R$. microplus counts within phase. For each phase, repeatabilities are in diagonals (in bold), and correlations are above diagonals.

\begin{tabular}{|c|c|c|c|c|c|}
\hline \multirow[b]{2}{*}{ Phase } & \multirow[b]{2}{*}{ Species } & \multirow[t]{2}{*}{ Count of R. microplus } & \multicolumn{3}{|c|}{ Copy numbers (NC) } \\
\hline & & & A. marginale & B. bigemina & B. bovis \\
\hline \multirow[t]{4}{*}{1} & R. microplus & 0.06 & -0.11 & 0.11 & 0.10 \\
\hline & A. marginale & & 0.23 & -0.15 & 0.09 \\
\hline & B. bigemina & & & 0.04 & 0.02 \\
\hline & B. bovis & & & & 0.19 \\
\hline \multirow[t]{4}{*}{2} & R. microplus & 0.20 & 0.15 & 0.00 & 0.02 \\
\hline & A. marginale & & 0.48 & -0.13 & 0.05 \\
\hline & B. bigemina & & & 0.19 & 0.00 \\
\hline & B. bovis & & & & 0.35 \\
\hline \multirow[t]{4}{*}{3} & R. microplus & 0.18 & 0.10 & 0.01 & 0.17 \\
\hline & A. marginale & & 0.38 & -0.07 & 0.16 \\
\hline & B. bigemina & & & 0.32 & 0.15 \\
\hline & B. bovis & & & & 0.17 \\
\hline \multirow[t]{4}{*}{4} & R. microplus & 0.33 & 0.04 & 0.08 & 0.12 \\
\hline & A. marginale & & 0.25 & -0.02 & -0.13 \\
\hline & B. bigemina & & & 0.12 & 0.24 \\
\hline & B. bovis & & & & 0.31 \\
\hline
\end{tabular}

moderate, where lower and higher repeatability estimates were found in phases 1 and 4, respectively, while in phases 2 and 3 they were similar (Table 3). Repeatability estimates of CN were also observed between low to moderate and had not presented a specific trend. The lowest repeatability values occurred in phase 3 for $B$. bovis, and at phase 1 for both $B$. bigemina and $A$. marginale. The highest repeatabilities were observed in phase 2 for $B$. bovisand $A$. marginale and at phase 3 for $B$. bigemina (Table 3 ).

The estimated correlations between the $\mathrm{CN}$ of different hemoparasites within each phase were low (between -0.15 and +0.15 ) and ranged between the phases, with no definite trend in most situations (Table 3). Only three of the 24 correlation estimates were greater than 0.15 . However, all negative correlations involved $A$. marginale, and especially with $B$. bigemina $\mathrm{CN}$, the values were all negative and increased from -0.13 in phase 1 to -0.03 in phase 4 . Between the two babesias, the estimated correlations were close to zero in the first two phases, being slightly higher in phases $3(0.15)$ and $4(0.24)$.

\section{Discussion}

Selection programs for improvement of host resistance against ticks and tick-borne diseases could be considered an important strategy for reduction of expenses with treatment and prophylaxis management, which implicates in the reduction of the susceptibility of a population in a given endemic area, and consequently in a decline of region's parasite load. However, there are scarce information, experimental models, and tools available to successfully carry these studies in natural field conditions. Moreover, there are no previous studies comparing old and new Canchim lineages regarding resistance to both ticks and hemoparasites. In our study, significant higher tick counts and B. bovis CN levels were observed in NL compared to OL, at phase 2. However, for the other evaluated hemoparasite infection levels there were no significant differences between two lineages during the whole experiment. These results were unexpected since NL presents a higher level of heterosis. We hypothesized that regarding genetic selection program of NL herd, over the years, tick resistance trait was not considered among objectives, leading to this result. Our study suggests that OL lineage could be relevant for the selection of Canchim cattle considering higher levels of resistance to both ticks and $B$. bovis infection.

As expected, significant effects of collection for tick counts were found during all phases, since is well known that climatic conditions are able to influence the development of free-living tick stages in pastures (Sutherst et al., 1988; Jongejan and Uilenberg, 2004). The tropical 
climate of the analyzed region in this experiment is characterized by hot and humid summers and moderated cool and dry winters. These conditions, in general, favored the tick life cycle in pastures throughout the study period, including in the drier months.

The estimated repeatabilities for tick counts in the present study ranged from low (close to zero in the first phase) to moderate $(0.38$ in the last phase). In a previous study, Giglioti et al. (2016) evaluated the repeatability of $R$. microplus count in two measurements in Angus animals and found values close to zero (0.05). These findings were similar to results observed at phase one from this study. On the other hand, other previous studies, evaluating different breeds, have found results close to our results from phases three and four (Madalena et al., 1985; Guaragna et al., 1988; Mackinnon et al., 1991; Andrade et al., 1998; Fraga et al., 2003). It was previously observed that large numbers of tick counts performed frequently and spaced by short intervals, under controlled environmental conditions, may be required for studies aiming to evaluate animal tick resistance (Giglioti et al., 2016), Thus, we suggest that animals age and the number of evaluations are also able to influence repeatability of tick counts, and consequently may have an important role in experimental studies focusing tick host resistance.

The qPCR assays used in the present study showed high specificity and sensitivity for quantification of copy numbers of the $m t-c y B$ gene of $B$. bovis and $B$. bigemina and $A$. marginale $m s p 1 b$, as already reported in previous studies (Buling et al., 2007; Carelli et al., 2007; Giglioti et al., 2016; Giglioti et al., 2017). qPCR assays used were able to detect all three species of hemoparasites DNA in the almost whole group of blood samples evaluated. Almost all animals from all collections presented quantifiable levels of $A$. marginale DNA, whereas DNA copy levels of $B$. bovisand $B$. bigemina decreased in the end of phase 4 (May 2015 onward), when the highest percentages of negative animals were observed. Recent studies using same qPCR protocols for $B$. bovis and $B$. bigemina showed levels of infection for these parasites equal or close to 100\% (Bilhassi et al., 2014; Giglioti et al., 2016; Giglioti et al., 2017). However, these studies have evaluated levels of Babesia spp. infection in one or two collections, and not during over time. In another previous study performed in the same region of present study, using 120 animals (calves and cows) from four different genetic groups (Oliveira et al., 2008), a qualitative PCR assay for B. bigemina presented $100 \%$ of positive animals. Due to qualitative nature of the technique, it was not possible to verify variations in infection levels among the different groups. Nevertheless, these authors verified that infection was independent of the animals' age, differently from the present study, in which showed approximately $45 \%$ of $B$. bigemina positive animals with 29 to 33 months of age.

There are still few studies of the repeatability and correlations for hemoparasite infection levels obtained through molecular techniques. In our study, estimated repeatabilities for hemoparasites levels ranged from low to moderate, influenced by animal's age. Giglioti et al. (2016) studied the infection levels of $B$. bovis and B. bigemina following the same method of this study in Angus cattle, and estimated repeatability values for $B$. bovis and $B$. bigemina of 0.02 and 0.10 , respectively, in the case of $B$. bigemina, close to that estimated in phase 1 . In the case of $B$. bovis $\mathrm{CN}$, the lowest estimated repeatability ( 0.17 in phase 3 ) was much higher than that estimated by those authors. Considering only the phases in which the lowest repeatability was found in the present study, we can infer that the level of parasitemia for both species varies more in function of environmental effects, so observation in a single collection would not be a good indicator for the subsequent collection, as suggested by Giglioti et al. (2016). However, moderate repeatability was also observed for all species ( 0.35 for $B$. bovis in phase 2, 0.32 for $B$. bigemina in phase 3 and 0.48 for A. marginale in phase 2). Repeatability is a parameter that depends on multiple factors, as genetic population and environment. Even, since the main difference between present study and that developed by Giglioti et al. (2016) was the breed we supposed that most differences in the obtained results could be attributed to genetic factors inherent to these breeds. Angus is a $100 \%$
Taurine breed while Canchim was originated from crosses between Taurines and Zebus. Besides that, the lower repeatability values found by those authors for $\mathrm{CN}$ of $B$. bovis (0.10) may also be due to lower accuracy resulted from the lower number of evaluations. Phase 1 was composed by young animals ranging from 8 to 13 months of age, when animals are still developing complete immunocompetence (Chase et al., 2008), then, it could be also an additional factor related to lowest repeatability values of parasite levels.

Most of studies comparing host resistance between young and adult animals comprise experimentally infected animals with separated isolates of each Babesia species, differently from natural field infection evaluated in our study. These studies have shown higher resistance of young animals compared to adults (Trueman and Blight, 1978; Goff et al., 2001). Despite both young and adult cattle are susceptible to Babesia infection when they are firstly exposed, younger animals have stronger innate resistance. This situation, unusual in most of infectious diseases, is known as inverse age resistance, in which the clinical signs can be slighter if first infection occurs when animals are very young, and after recovery, low levels of parasitemia persist for long periods without causing apparent damage to animals (Zintl et al., 2005). This phenomenon may also be variable between animals, influencing on the repeatability. Considering the repeatability estimated for $\mathrm{CN}$ of $\mathrm{B}$. bigemina and A. marginale, the highest levels occurred in phases 2 and 3 , when the animals had ages between 13 and 24 months. However, for $B$. bovis, the same did not occur. The abrupt declines in the levels of $B$. bovis infection in collections 13 and 16, followed by increasing during subsequent collections, probably have influenced the estimation of repeatability in phase 3 . High repeatabilities indicate that genetic and permanent environmental factors intrinsic to each animal are more important for the expression of the trait studied, while low repeatabilities indicate that the most important is the environment to which the animal is subjected at the moment of measurement. Thus, measurements in phases when the repeatability is higher provide a better indicative of the animal's value for the trait. In this sense, the estimates here obtained indicate that for hemoparasite infection levels, the best animal ages to evaluate host resistance are between 13 and 24 months, while for the tick count, the most recommended is after 24 months of age. Bilhassi et al. (2014) studied the level of B. bovis infection in cows and calves of three different genetic groups (Angus, Nelore and Angus $\mathrm{x}$ Nelore) and found that the Nelore and Angus x Nelore calf groups presented higher level of infection than the cows, whereas for the Angus breed the differences were not significant. In the present study, we found that the $\mathrm{CN}$ of $B$. bovisand B. bigemina decreased throughout the collection period, being more evident during phases 1 and 4. Levels of A. marginale DNA followed the same profile, although in a slighter degree. Our findings are similar to those of these authors, considering that the Canchim breed originates from cross of Taurine and Zebu cattle. The estimated correlations between $R$. microplus counts and level of hemoparasites DNA were low, wherein the highest correlations were found for $A$. marginale (0.15) in phase 2 and $B$. bovis in phases 3 and 4 ( 0.17 and 0.12 ). The other correlations estimated between $\mathrm{CN}$ and tick counts were close to zero, similar to the results found ina previous study (Giglioti et al., 2016). The estimated correlations between the $\mathrm{CN}$ for two babesias were low. In the first two phases, the correlations were close to zero, whereas in phases 3 and 4 they were higher $(0.15$ and 0.24). These results indicate that it is not the same genetic or environmental factors contributing to variations in hemoparasite infection levels. Furthermore, these low correlations show that levels of infection by a determined hemoparasite species in just one animal will not be useful to predict levels for other species. The correlation verified by Giglioti et al. (2016) of 0.30 for the CN between the two babesias is close to that found in phase 4 in the present study. The low correlations found among the $\mathrm{CN}$ of the three hemoparasite species with the $R$. microplus counts indicate that variations in tick loads in an animal do not lead to variations in hemoparasite levels.

In general, the repeatability estimates varied from low to moderate, 
depending on the phases and hemoparasite species. Based on the highest repeatability estimates observed at phases 2 and 3, we can infer that measurements collected during this period may be a good indicator of subsequent observations of the same animal. In other words, animals with higher $\mathrm{CN}$ in one measurement also have higher $\mathrm{CN}$ in the next measurement. The repeatability values estimated by Giglioti et al. (2016) regarding B. bigemina and B. bovis levels (0.02 and 0.10) allowed the conclusion that variations of Babesia levels are most related to factors related to each collection than intrinsic animal factors. Based on the present study, we can consider that in the Canchim breed, at least in some phases of life, intrinsic factors of each animal may be partially responsible for maintaining of parasitemia level. Therefore, studies to evaluate the resistance to these parasites should consider mainly the phases with higher repeatabilities.

\section{Conclusions}

The qPCR technique was suitable to estimate parasitemia levels of Babesia bovis, B. bigemina, and Anaplasma marginale in Canchim cattle from blood samples during 24 months of the whole experiment. Our findings showed that the levels of infection by protozoans decreased with the age of the animals, unlike observed for A. marginale, which maintained more stable levels throughout the experiment. The repeatabilities of $\mathrm{CN}$ of the hemoparasites showed variations between the different phases considered, suggesting that the importance of variations between individuals regarding resistance to the agents studied depends on the animals' age and that the heritability of resistance to hemoparasites has at most moderate values. The highest repeatability estimates for hemoparasite infection levels for animals aged 13-24 months (phases 2 and 3 ) indicate animals with this age range are the most suitable for evaluation to identify host resistance phenotype. The absence of associations between the NC of B. bovis, B. bigemina, and A. marginaleand between tick counts with these hemoparasites indicates it is not possible to use resistance information to one of the parasites for evaluation of the animals concerning the other parasites.

\section{Acknowledgments}

This research project was supported by the São Paulo State Research Support Foundation (FAPESP) (grant \#2013/20513-5, 2016/07216-7) and the Brazilian Agricultural Research Corporation (Embrapa SEG 02.12.02.008.00.00).

\section{References}

Andrade, A.B.F., Silva, R.G., Costa, A.J., Rocha, U.F., Landim, V.J.C., 1998. Genetic and environmental aspects of the resistance of zebu cattle to the tick Boophilus microplus. In: 6, 1998 Armidale, NSW, Australia. World Congress on Genetics Applied to Livestock Production 27. pp. 339-342 (Proceedings... Armidale 6th World Congress on Genetics Applied to Livestock Production. Armidale).

Bilhassi, T.B., Oliveira, H.N., Ibelli, A.M.G., Giglioti, R., Regitano, L.C.A., OliveiraSequeira, T.C.G., Bressani, F.A., Malagó, W., Resende, F.D., Oliveira, M.C.S., 2014 Quantitative study of Babesia bovis infection in beef cattle from São Paulo state, Brazil. Ticks Tick Borne Dis. 5, 234-238.

Bock, R., Jackson, L., de Vos, A., Jorgensen, W., 2004. Babesiosis of cattle. Parasitology 129 (Suppl), S247-S269.

Brown, W., Norimine, J., Knowles, D., Goff, W., 2006. Immune control of Babesia bovis infection. Vet. Parasitol. 138 (1/2), 75-87.

Buling, A., Criado-Fornelio, A., Acenzo, G., Benitez, D., Barba-Carretero, J.C., FlorinCristensen, M., 2007. A quantitative PCR assay for the detection and quantification of $\mathrm{B}$ bovis and B. bigemina. Vet. Parasitol. 147, 16-25.

Calder, J.A., Reddy, G.R., Chieves, L., Courtney, C.H., Littell, R., Livengood, J.R., Norval, R.A., Smith, C., Dame, J.B., 1996. Monitoring Babesia bovis infections in cattle by using PCR-based tests. J. Clin. Microbiol. 34, 2748-2755.

Caraguel, C.G., Stryhn, H., Gagné, N., Dohoo, I.R., Hammell, K.L., 2011. Selection of a cutoff value for real-time polymerase chain reaction results to fit a diagnostic purpose: analytical and epidemiologic approaches. J. Vet. Diagn. Invest. 23 (1), $2-15$

Cardoso, F.F., Gomes, C.C.G., Sollero, B.P., Oliveira, M.M., Roso, V.M., Piccoli, M.L., Higa, R.H., Yokoo, M.J., Caetano, A.R., Aguilar, I., 2015. Genomic prediction for tick resistance in Bradford and Hereford cattle. J. Anim. Sci. 93, 2693-2705.

Carelli, G., Decaro, N., Lorusso, A., Elia, G., Lorusso, E., Mari, V., Ceci, L., Buonavoglia, C., 2007. Detection and Quantification of Anaplasma Marginale DNA in Blood Samples of Cattle by Real-time PCR 124. pp. 107-114.
Chase, C.C., Hurley, D.J., Reber, A.J., 2008. Neonatal immune development in the calf and its impact on vaccine response. Vet. Clin. North Am. Food. Anim. Pract. 24, 87-104.

Clark, I.A., Jacobsen, L., 1998. Do babesiosis and malaria share a common disease process? Ann. Trop. Med. Parasitol. 92, 483-488.

Fraga, A.B., De Alencar, M.M., De Figueiredo, L.A., Razook, A.G., Dos Santos, Conçalves, Cyrillo, J.N., 2003. Análise de fatores genéticos e ambientais que afetam a infestação de fêmeas bovinas da raça caracu por carrapatos (Boophilus microplus). Rev. Bras. Zootec. 32 (6), 1578-1586.

Giglioti, R., Oliveira, H.N., Santana, C.H., Ibelli, A.M.G., Néo, T.A., Bilhassi, T.B., Rabelo, M.D., Machado, R.Z., Brito, L.G., Oliveira, M.C.S., 2016. Babesia bovis $</$ it $>$ and Babesia bigemina infection levels estimated by qPCR in Angus cattle from an endemic area of São Paulo state, Brazil. Ticks Tick-Borne Dis. 7, 657-662.

Giglioti, R., Oliveira, H.N., Ibelli, A.M.G., Bilhassi, T.B., Néo, T.A., Santana, C.H., Rabelo, M.D., Machado, R.Z., Chagas, A.C.S., Oliveira, M.C.S., 2017. Neither quantification by qPCR nor quantitative Elisa can be used to discriminate Angus cattle for resistance/susceptibility to Babesia bovis. Ticks Tick-borne Dis. 8 (3), 335-340.

Goff, W.L., Johnson, W.C., Parish, S.M., Barrington, G.M., Tuo, W., Valdez, R.A., 2001. The age-related immunity in cattle to Babesia bovis infection involves the rapid induction of interleukin-12, interferon-gamma and inducible nitric oxide synthase mRNA expression in the spleen. Parasite Immunol. 23, 463-471.

Guaragna, G.P., Carvalho, J.B.P., Figueiredo, A.L., Gambini, L.B., Barbosa, M.I.A., 1988. Efeito de fatores genéticos e ambientais na infestação natural de carrapatos (Boophilus microplus Canestrini) em bovinos leiteiros. Boletim de Industria Animal. Nova Odessa 45, 19-32.

Ibelli, A.M.G., Ribeiro, A.R.B., Giglioti, R., Regitano, L.C.A., Alencar, M.M., Chagas, A.C.S., PaçO, A.L., Oliveira, H.N., Duarte, J.M.S., Oliveira, M.C.S., 2012. Resistance of cattle of various genetic groups to the tick Rhipicephalus microplus and the relationship with coat traits. Vet. Parasitol. 186, 425-430.

Jongejan, F., Uilenberg, G., 1994. Ticks and control methods. Rev. Sci. Tech. 13 (4), $1201-1226$.

Jongejan, F., Uilenberg, G., 2004. The global importance of ticks. Parasitol 129, 3-14.

Ke, G.M., Cheng, H.L., Ke, L.Y., Ji, W.T., Chulu, J.L., Liao, M.H., Chang, T.J., Liu, H.J., 2006. Development of a quantitative Light cycler real-time RT-PCR for detection of avian reovirus. J. Virol. Methods 133, 6-13.

Kocan, K.M., de la Fuente, J., Guglielmone, A.A., Meléndez, R.D., 2003. Antigens and alternatives for control of Anaplasma marginale infection in cattle. Clin. Micro Rev. 16 (4), 698-712.

Mackinnon, M.J., Meyer, K., Hetzel, D.J.S., 1991. Genetic variation and covariation for growth: parasite resistance and heat tolerance in tropical cattle. Livest. Prod. Sci. 27, 105-122.

Madalena, F.E., Teodoro, R.L., Lemos, A.M., Oliveira, G.P., 1985. Causes of variation of field burdens of cattle ticks (B: microplus). Rev. Bras. Genét. 8 (2), 361-375.

Mahoney, D.F., Ross, D.R., 1972. Epizootiological factors in the control of bovine babesiosis. Aust. Vet. J. 48, 292-298.

Mahoney, D.F., 1962. Bovine babesiosis. Diagnosis of infection by a complement fixation test. Aust. Vet. J. 38, 48-52.

Oliveira, G.P., Alencar, M.M., 1987. Resistência de bovinos ao carrapato Boophilus microplus. I infestação artificial. Pesq. Agropec. Bras. 22 (4), 433-438.

Oliveira, G.P., Alencar, M.M., Freitas, A.R., 1989. Resistance of cattle to the tick Boophilus microplus. II Natural infestation. Pesq. Agropec. Bras. 24, 1267-1271.

Oliveira, M.C.S., Oliveira-Sequeira, T.C.G., Araujo Jr., J.P., Amarante, A.F.T., Oliveira, H.N., 2005. Babesia spp. infection in Boophilus microplus engorged female and eggs in São Paulo State, Brazil. Vet. Parasitol. 130, 61-67.

Oliveira, M.C.S., Oliveira-Sequeira, T.C.G., Regitano, L.C.A., Alencar, M.M., Néo, T.A., Silva, A.M., Oliveira, H.N., 2008. Detection of Babesia bigemina in cattle of different genetic groups and in Rhipicephalus (Boophilus) microplus tick. Vet. Parasitol. 155, $281-286$.

Oliveira, M.C.S., Bilhassi, T.B., Giglioti, R., Ibelli, A.M.G., Malagó Jr., W., Oliveira, H.N., 2014. Estudo da prevalência e do nível de infecção por Babesia bovis e Babesia bigemina em bovinos da raça Angus, Nelore e cruzados, criados em áreas endêmicas do Estado de São Paulo. Editoração Eletrônica, Embrapa Pecuária Sudeste, Boletim de Pesquisa e Desenvolvimento n. 37, p.26. ISSN: 1517-1981.

Oliveira-Sequeira, T.C.G., Oliveira, M.C.S., Araujo Jr., J.P., Amarante, A.F.T., 2005. PCRbased detection of Babesia bovis and Babesia bigemina in their natural host Boophilus microplus and cattle. Int. J. Parasitol. 35, 105-111.

Pfaffl, M.W., 2001. A new mathematical model for relative quantification in real-time RTPCR. Nucleic Acids Res. 29, E45.

Ramos, C.A.N., Araújo, F.R., Souza, I.I.F., Bacanelli, G., Luiz, H.L., Russi, L.S., Oliveira, R.H.M., Soares, C.O., Rosinha, G.M.S., Alves, L.C., 2011. Real-time polymerase chain reaction based on msa2c gene for detection of Babesia bovis. Vet. Parasitol. 176, 79-83.

Sahinduran, S., 2012. Protozoan diseases in farm ruminants. Available from: http://cdn. intechopen.com/pdfs/28686/InTech-Protozoan_diseases_in_farm_ruminants.pdf. Accessed on 9-11-2017.

Schetters, T.P., Eling, W.M., 1999. Can Babesia infections be used as a model for cerebral malaria? Parasitol. Today 15, 492-497.

Trueman, K.F., Blight, G.W., 1978. The effect of age on resistance of cattle to Babesia bovis. Aust. Vet. J. 54 (6), 301-305.

Vandesompele, J., De Preter, K., Pattyn, F., Poppe, B., Van Roy, N., De Paepe, A. Speleman, F., 2002. Accurate normalization of real-time quantitative RT-PCR data by geometric averaging of multiple internal control genes. Genome Biol. 3 RESEARCH0034.

Wharton, R.H., Utech, K.B.W., 1970. The relation between engorgement and dropping of Boophilus microplus (Canestrini) (Ixodidae) to the assessment of tick numbers on cattle. J. Aust. Entomol. Soc. 9, 171-182.

Wright, I.G., Goodger, B.V., 1988. Pathogenesis of babesiosis. In: Ristic, M. (Ed.), Babesiosis of Domestic Animals and Man. CRC Press, Boca Raton, pp. 99-118.

Zintl, A., Gray, J.S., Skerrett, H.E., Mulcahy, G., 2005. Possible mechanisms underlying age-related resistance to bovine babesiosis. Parasite Immunol. 27 (4), 115-120. 